\title{
Microencapsulation of Baker's Yeast in Gellan Gum Beads Used in Repeated Cycles of Glucose Fermentation
}

\author{
Camelia Elena Iurciuc (Tincu), ${ }^{1}$ Catalina Peptu, ${ }^{1}$ Alexandru Savin, ${ }^{1}$ \\ Leonard-Ionut Atanase, ${ }^{2,3}$ Kaies Souidi, ${ }^{4}$ Grahame Mackenzie, ${ }^{5}$ Patrick Martin, ${ }^{4}$ \\ Gerard Riess, ${ }^{6}$ and Marcel Popa ${ }^{1,2,3,7}$ \\ ${ }^{1}$ Department of Natural and Synthetic Polymers, Faculty of Chemical Engineering and Protection of the Environment, \\ "Gheorghe Asachi" Technical University, Prof. Dr. Docent Dimitrie Mangeron Str., No. 73, 700050 Iaşi, Romania \\ ${ }^{2}$ Faculty of Dental Medicine, "Apollonia" University, Iaşi, Romania \\ 3"Academician Ioan Haulica" Research Institute, Iași, Romania \\ ${ }^{4}$ Département Chimie, IUT Béthune, Université d'Artois, CS20819, 62408 Béthune, France \\ ${ }^{5}$ Department of Chemistry, University of Hull, Hull HU6 7RX, UK \\ ${ }^{6}$ LPIM, Université de Haute Alsace, 68093 Mulhouse, France \\ ${ }^{7}$ Academy of Romanian Scientists, Splaiul Independentei Str. 54, 050094 București, Romania
}

Correspondence should be addressed to Leonard-Ionuț Atanase; leonard.atanase@yahoo.com and Marcel Popa; marpopa2001@yahoo.fr

Received 11 April 2017; Accepted 10 May 2017; Published 11 July 2017

Academic Editor: Angel Concheiro

Copyright (C) 2017 Camelia Elena Iurciuc (Tincu) et al. This is an open access article distributed under the Creative Commons Attribution License, which permits unrestricted use, distribution, and reproduction in any medium, provided the original work is properly cited.

\begin{abstract}
The purpose of this work is to prepare ionically cross-linked (with $\mathrm{CaCl}_{2}$ ) gellan particles with immobilized yeast cells for their use in repeated fermentation cycles of glucose. The study investigates the influence of ionic cross-linker concentration on the stability and physical properties of the particles obtained before extrusion and during time in the coagulation bath (the cross-linker solution with different $\mathrm{CaCl}_{2}$ concentrations). It was found that by increasing the amount of the cross-linker the degree of cross-linking in the spherical gellan matrix increases, having a direct influence on the particle morphology and swelling degree in water. These characteristics were found to be very important for diffusion of substrate, that is, the glucose, into the yeast immobilized cells and for the biocatalytic activity of the yeast immobilized cells in gellan particles. These results highlight the potential of these bioreactors to be used in repeated fermentation cycles (minimum 10) without reducing their biocatalytic activity and maintaining their productivity at similar parameters to those obtained in the free yeast fermentation. Encapsulation of Saccharomyces cerevisiae into the gellan gum beads plays a role in the effective application of immobilized yeast for the fermentation process.
\end{abstract}

\section{Introduction}

Saccharomyces cerevisiae has been used for thousands of years as yeast in the fermentation processes for human household interest, especially for the production of wine, brewer's yeast, and doughs. The preparation of native yeast, even when required in large quantities in industrial applications, is a facile and low-costing process. Over many years, researchers appear to have overlooked the possibility of its immobilization on macromolecular or any other kind of solid support [1]. Nevertheless, recent studies [2-4] have pointed out the interest of attaching yeast to polymeric matrices. The following practical advantages of using immobilized yeast cells are important for industrial scale-up: (a) increasing productivity of the fermenter which will permit the use of important flow rates in a continuous operating mode, avoiding the yeast cells destruction and obtaining of high yields in the fermentation processes [5-7]; (b) improving the process control, which is done by the continuous operation, product separation, and removal of the metabolic inhibitors, as well as by the improving product recovery (continuous extraction); (c) permitting recycling of the biological catalyst; 
(d) maintaining the biocatalyst in a stable and active state (the extension of the stationary phase); (e) protecting sensitive cells against destruction (e.g., shear forces); and (f) reducing the risk of microbial contamination.

Over the last three decades, an increased interest has been shown by researchers in the use of natural polysaccharides as building matrices (spheres, capsules, fibers, or membranes) for the immobilization of microbial, plant, or animal cells. New technologies using immobilized cells on polymer matrices have been elaborated, with various practical applications, such as in the biomass production, the preparation of high value compounds, the biological treatment of polluted waters, the controlled drug release, and the microbial biosensors [5, 7-9].

Cell immobilization has been defined as the attachment of the cells or their inclusion in a confined zone of space in such a way as to maintain their catalytic activity and, if possible or necessary, to be used repeatedly or unlimitedly. Yeasts, especially Saccharomyces species, are generally chosen for the production of ethanol due to an important fermentation capacity, a good tolerance to ethanol and other inhibitors, and their capability of rapid growth under anaerobic conditions which are characteristic of fermentation processes $[10,11]$.

Numerous cell immobilization techniques have been developed by using physical (adsorption, inclusion into porous polymers as films, particles, or microcapsules) or chemical covalent linkages to the macromolecular support $[1,12,13]$. Several authors have employed physical localization on granular matrices as it offers better protection of immobilized biocatalysts $[14,15]$. This can be done by applying milder conditions as those used for the production of spherical microparticles, with application as column filling materials.

It is important to note that coimmobilization based on biological polymers is more widely used due to its nontoxicity and biocompatibility. For these reasons, polysaccharides represent by far the most often analyzed polymer class for this application, as they can be found in nature and are easily obtained and chemically modified. Different types of polysaccharides used include alginic acid, most commonly investigated [16-19], carrageenan, chitin and chitosan, gellan gum, and pectin and agar gum $[20,21]$, and cellulose-based materials [22]. Polysaccharides constitute a highly flexible, biocompatible, and nontoxic matrix that confers protection and stability to immobilized cells $[1,23,24]$. Therefore, this choice of the polymeric support is preferred for immobilizing yeast cells subject in order to obtain favorable process conditions. The inclusion of the yeast cells in alginates by ionotropic gelling process in the presence of a variety of divalent and trivalent ions has been extensively applied in the immobilization technologies [25]. However, the poor structural stability of the alginate particles immobilized with yeast cells opens the way for the use of synthetic polymers as matrices for the cell immobilization $[19,26]$. Polyacrylamide gels were found to be suitable for the immobilization of yeast cells as they present higher stability than the alginates [27]. Some approaches made to stabilize the alginate gels include direct covalent cross-linking and covalent grafting of alginates with synthetic polymers. Moreover, the density and the mechanical strength of the alginate gels may be increased by incorporating inorganic materials such as silica, sand, and aluminum $[15,28]$. Other types of commonly used substrates are glass or ceramics [29], $\gamma$-alumina [30], silica sol-gel films [31], polyacrylamide gels [32], and combinations of various materials [33]. Silicon-based materials have attracted attention because of the physical and chemical properties of silica, such as $\mathrm{Si}-\mathrm{O}$ bond strength $\left(425 \mathrm{~J} \cdot \mathrm{mol}^{-1}\right)$ which provides great stability. Another method used to increase the strength of the alginate gels consists in the coating of the hydrogel particles obtained by ionic cross-linking, in the presence of various cations such as calcium and barium, with a layer of silica gel [34].

The choice of support for the yeast cells immobilization is essential. The characteristics which must be fulfilled are good mechanical and chemical stability, nontoxicity, and biocompatibility with cells as well as high diffusion coefficient for both substrates and for fermentation products [35].

Gellan gum is an extracellular anionic heteropolysaccharide obtained by commercial fermentation of a pure culture of bacterium Sphingomonas elodea. According to O'Neill et al. [36], gellan gum is composed of tetrasaccharide (1.3- $\beta$-Dglucose, 1.4- $\beta$-D-glucuronic acid, 1.4- $\beta$-D-glucose, and 1,4$\alpha$-L-rhamnose) repeating units with a molar ratio of $2: 1: 1$ containing about $1.5 \%$ acyl groups as acetyl and glycerate molecules per unit (Figure 1).

Gellan, as spherical particles obtained by ionotropic gelling process, has already been used to immobilize yeast cells and a biocatalyst, with real application in the sparkling wine production technology, was obtained [37].

Tan et al. [38] have immobilized yeast cells using gellan as support by an emulsifying method and have indicated the possibility of reusing the resulting microbioreactors. The production of ethanol during the first three cycles was comparable to that obtained in the presence of free yeast. Moreover, these authors have demonstrated that the microbioreactors are stable and readily recovered from the fermentation medium by filtration and can be reused for at least 10 cycles of fermentation with a relatively high yield of ethanol [38].

The importance of minerals in the fermentation and distillation processes has been long time overlooked. However, the metal ions have a significant impact on important parameters, including the conversion rate of sugar into ethanol, the final yield in ethanol, the growing and multiplying yeast, the cell viability, the stressors, and the yeast flocculation behavior $[39,40]$.

The purpose of this study is related to the preparation of bioreactors in the form of gellan spherical particles containing immobilized yeast cells and ionically cross-linked with $\mathrm{CaCl}_{2}$ by using the extrusion method. $\mathrm{CaCl}_{2}$ was selected as a cross-linking agent as the calcium ions may play an important role in protecting yeast cells from the toxic effects of ethanol. This characteristic is also valid for the magnesium or zinc ions. The calcium ions, in high concentrations, can replace the magnesium in a number of biochemical processes which can lead to cell growth and to maintaining the cell viability. Also, increasing the calcium concentration in the fermentation medium has a buffer effect which prevents the 


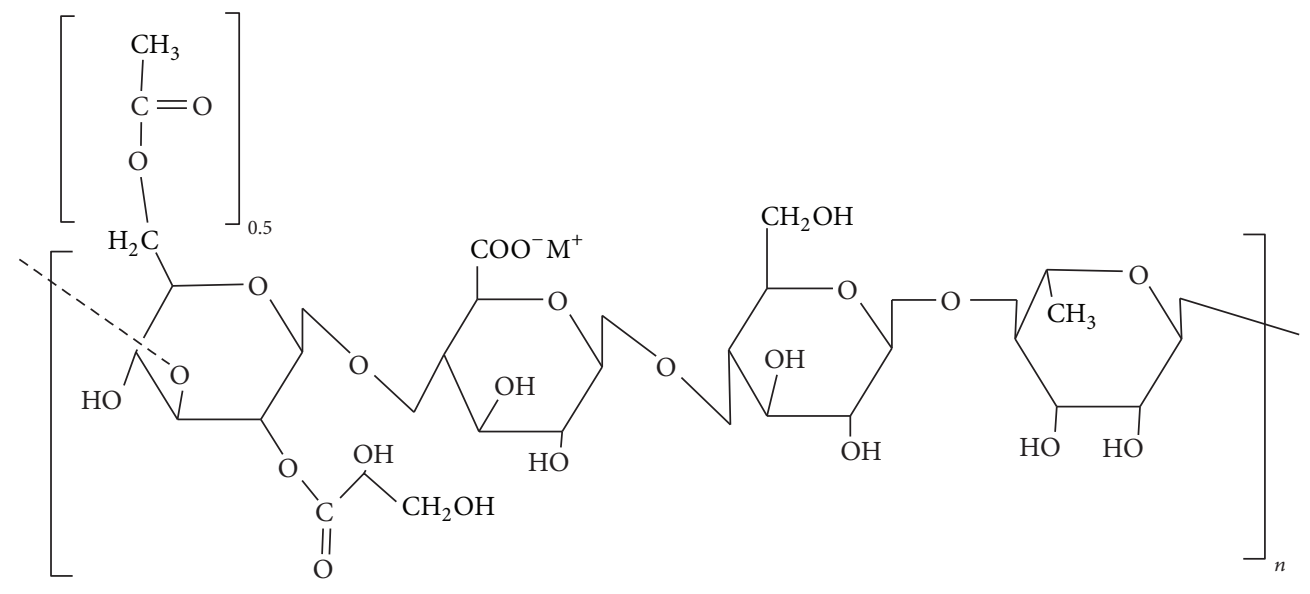

FIGURE 1: Chemical structure of gellan.

increase of $\mathrm{pH}$ in the environment and leads to an increased fermentation efficiency $[41,42]$.

The originality of this study is primarily related to the pregelification of the gellan solution, before the capillary extrusion, using low concentrations of $\mathrm{CaCl}_{2}$ which leads to a viscosity increase of the polysaccharide solution. This increased viscosity promotes the extrusion process and increases the stability of the obtained particles. Another original aspect is the assessment of structural stability by turbidimetric determination of the aqueous or alcoholic medium in which the particles are suspended. For the first time, the swelling capacity in aqueous media of the particles with immobilized yeast cell was evaluated as a function of the cross-linking degree. It is well known that this feature has an influence on the substrate diffusion and also on the diffusion of fermentation products in and out of particles.

The obtained particles were characterized morphologically and physicochemically and their fermentative activity was tested and compared with that obtained in the presence of free yeast. The recovery and the recycling of these particles were also investigated.

\section{Materials and Methods}

2.1. Materials. Kelco Biopolymers supplied gellan of the KELCOGEL food grade type having a molar mass between $2 \times 10^{5}$ and $3 \times 10^{5}$ Da for deacetylated gellan.

Calcium chloride was used as solution, in distilled water, with concentrations between $1 \%$ and $3 \%$ (wt).

For immobilization, a commercial bakery yeast strain in a compressed form was used, from Pakmaya-Romania, with a cell content of $30 \%$.

Saccharomyces cerevisiae cell characteristics are as follows: diameter is $2-8 \mu \mathrm{m}$; volume is $0.8-2 \times 10^{-3} \mathrm{~cm}^{3}$; mass is $0.2-0.4 \times 10^{-10} \mathrm{~g}$; number of cells $/ \mathrm{g}$ is $8-14 \times 10^{9}$; and specific surface is $8-14 \times 10^{9}\left(\mathrm{~m}^{2} / \mathrm{g}\right)$.

This type of yeast was selected due to the fact that it represents a cell biomass of the top fermenting yeast and is composed of living cells capable of producing fermentation of sugars without requiring a culture medium. These cells absorb the easiest hexoses (glucose) and then sucrose and maltose [43-47]. Glucose monohydrate was supplied by S.C. Chemical Company S.A., Iaşi, Romania.

\subsection{Methods}

2.2.1. Preparation of the Immobilized Cell System. Gellan powder $(0.25 \mathrm{~g})$ was dispersed in distilled water $(25 \mathrm{~mL})$ at $20^{\circ} \mathrm{C}$. After stirring and heating to $90^{\circ} \mathrm{C}$, the suspension with a concentration of $1 \%$ changed into a clear solution. To this solution was added, under stirring, a sequence of four aliquots $(1.25 \mathrm{ml})$ of hot solutions of $\mathrm{CaCl}_{2}$ with increasing concentrations, such as $0.1,0.3,0.4$, and $0.5 \%$; finally, the obtained solution was cooled to $40^{\circ} \mathrm{C}$.

The suspension of yeast in water $(1.25 \mathrm{~g} / 5 \mathrm{~mL}$, containing $0.375 \mathrm{~g}$ cells) was mixed with the gellan solution at $40^{\circ} \mathrm{C}$ and stirred for 10 minutes, at $450 \mathrm{rpm}$, until the mixture became homogeneous and the obtained gel was cooled to $30^{\circ} \mathrm{C}$. The gel containing the yeast cells (preextrudate) was added dropwise (extruded) at a constant force from a syringe (inner diameter of the needle: $600 \mu \mathrm{m}$; length of the needle: $30 \mathrm{~mm}$ ) into a concentrated solution of calcium chloride in water (125 mL, with different concentrations: 2, 3, and $4 \mathrm{~g} \mathrm{CaCl}_{2} / 100 \mathrm{~mL}$ ). Upon contact with $\mathrm{CaCl}_{2}$ solution, ionotropic gelification transformed the drops into gelled particles. After 1 hour of stabilization in the concentrated solution of calcium chloride, the particles containing the yeast immobilized in gellan were separated by filtration. The water swollen particles were stored at $4^{\circ} \mathrm{C}$ in sealed containers before characterization.

2.2.2. Particles Stability. Gellan particles with immobilized yeast cells were suspended in the supernatant (cross-linking solution) for $24 \mathrm{~h}$ and after that in distilled water for another $48 \mathrm{~h}$ in order to determine their stability in time. After 12 hours, yeast cells and gel fragments were detached having as consequence the increase of the suspension turbidity. Particles, with and without encapsulated yeast, were stored either in the supernatant (from the coagulation bath) or in double-distilled water. Between analyses, the particles 
immobilized with yeast cells were stored at $4^{\circ} \mathrm{C}$ in sealed containers.

Cell immobilization in gellan particles, as well as in other polymers, protects the biocatalyst from the medium, sometimes aggressive, in which the fermentation takes place. It is required that these particles be stable in alcoholic solutions (formed after fermentation) with a concentration of $80 \mathrm{~g} \cdot \mathrm{L}^{-1}$, which can justify the separation of alcohol by distillation and also enable their reutilization. For this reason, several types of particles were analyzed in terms of stability in an alcoholic solution of $100 \mathrm{~g} \cdot \mathrm{L}^{-1}$, by monitoring the transmittance of the alcoholic medium, in which they were suspended, at various time periods (between 12 and 84 hours). The transmittance measurements must be carried out under identical conditions to those at which the fermentation occurs. Thus, before each measurement of the transmittance, the samples were maintained at $30^{\circ} \mathrm{C}$, the temperature at which the fermentation process occurs, for $255 \mathrm{~min}$, which is the duration of a fermentation cycle.

Turbidity determinations of the suspension medium were used as a qualitative indication of mechanical stability, particles integrity, and immobilization yield. This property was evaluated by measuring transmittance of suspensions at $550 \mathrm{~nm}$ on a BOECO S22 UV-VIS spectrophotometer. The transmittance measurements were performed in triplicate and the standard deviations were within limits of $\pm 0.3 \%$.

2.2.3. Viability and Amount of Immobilized Yeast Cells. This analysis was performed in order to determine whether the immobilized particles are stable and whether the cells maintain their viability in the medium in which they are stored. It is considered that a higher quantity of cells may diffuse in the storage medium from the less stable particles.

The cell viability and number of yeast cells in the immobilized yeast suspensions were determined using an optical microscope and a counting chamber. The yeast cells, in dilute solution, were treated with methylene blue in order to reveal the physiologically inactive cells. Under the action of methylene blue, inactive cells were colored in blue, whereas the active ones were colorless. This phenomenon appears as a consequence of the fact that reductases are only active in reducing the methylene blue in active living cells. Nonviable cells (autolysed) were counted with the counting chamber Marienfeld (Neubauer).

The yeast cell concentration (number of yeast cells $/ \mathrm{ml}$ ) in the extrusion solution was determined after 12 and 24 hours, respectively. Then the particles with immobilized yeast cells were washed and resuspended in double-distilled water and the cell concentration was determined after 24 hours and 48 hours, respectively.

Depending on the number of living and dead (autolysed) yeast cells found in the extrusion solution, after 12 and 24 hours, respectively, cell viability $\left(V_{c}\right)$ determinations were made as a percentage of living cells to total cells counted in the supernatant, according to the following equation:

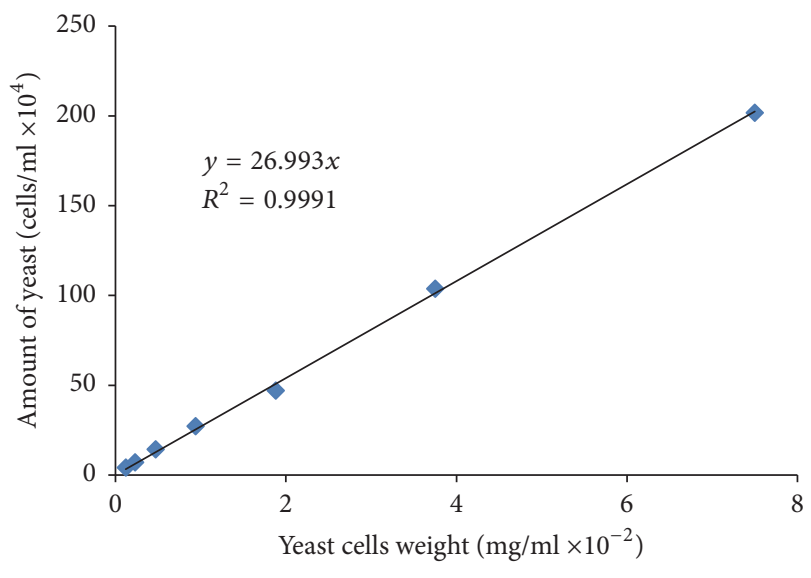

FIGURE 2: Calibration curve that correlates the number of yeast cells with their mass.

The number of cells counted in the suspension solutions versus the relative mass of immobilized cells ( $\mathrm{g}$ ) was used to draw the plot given in Figure 2. The theoretical quantity of immobilized cells was determined as the difference between the initial amount of yeast cells used and the number of yeast cells found in the supernatant (the medium in which particles with immobilized cells were suspended). The cell viability measurements were performed in triplicate and the standard deviations were within the limits $( \pm 0.3 \%)$.

The following procedure was used in order to determine if the cells proliferate in the polymer matrix between different fermentation cycles. From each sample tested for the fermentative activity, 2-3 particles were precisely weighted and then mechanically disrupted by means of ULTRA-TURRAX at $2000 \mathrm{rpm}$ in $100 \mathrm{~mL}$ of double-distilled water in order to obtain a homogeneous dispersion of the cells. By staining these cells dispersion with methylene blue, using the method described above, the cell concentration and the cell viability in the particles were determined. It was possible to evaluate the amount of particles which is found in the cells after each fermentation cycle ( $\mathrm{g}$ cell/g particles) by taking into account the number of cells $/ \mathrm{ml}$ (cell concentration) of the drawn calibration curve.

2.2.4. Swelling Degree of the Particles. As the particles obtained in this study have a hydrogel behavior, it was worthwhile to calculate their swelling degree (SD\%). A known amount of dry samples $\left(M_{\mathrm{dry}}\right)$ was suspended in $5 \mathrm{ml}$ of water at $30^{\circ} \mathrm{C}$ and the mass of the swollen sample $\left(M_{\text {swollen sample }}\right)$ was determined by weighing the particles every hour until the amount of retained water remained constant. The mass of water retained $\left(M_{\text {water }}\right)$ represents the difference between the mass of the swollen sample and the mass of the dry sample. The swelling degree was calculated using the following equation:

$$
V_{c}=\frac{N \text { living cells }}{(N \text { living cells }+N \text { dead cells })} \times 100 \text {. }
$$

$$
\mathrm{SD}(\%)=\frac{M_{\text {water }}}{M_{\text {dry sample }}} \times 100
$$


2.2.5. Analysis by Scanning Electron Microscopy (SEM). Gellan particle morphology, in both wet and dry forms, with and without immobilized yeast, was analyzed by scanning electron microscopy, using HITACHI SU 1510 (Figure 5). Water swollen particles prepared as cross-sectional on ice sample were analyzed. The dried particles were metalized with gold (cathodic spraying device, 108 Cressington Auto) for SEM examination.

2.2.6. The Fermentative Activity of the Gellan Particles with Immobilized Yeast Cells. The ability of the particles with immobilized yeast cells to function in glucose fermentation was tested using a glass fermenter with a volume of $200 \mathrm{~mL}$; the glucose solution contained glucose $(4 \mathrm{~g})$, distilled water $(50 \mathrm{~mL})$, and $\mathrm{CaCl}_{2}(0.15 \mathrm{~g})$ and was adjusted to $\mathrm{pH} 5$.

Although it is not considered a critical factor to affect the performance of the fermentation, the $\mathrm{pH}$ plays an important role in the uptake of the metal cations of the yeast cells during fermentation. Previous research reported that the optimum $\mathrm{pH}$ for the fermentation medium is between 4.5 and 5 [4850].

Fermentation was conducted in a cylinder at $30^{\circ} \mathrm{C}$ and the emitted $\mathrm{CO}_{2}$ was monitored in order to determine the amount of fermented glucose and thus the process productivity. Fermentation cycles last 255 minutes, and the amount of released $\mathrm{CO}_{2}$ was recorded every 15 minutes. After each fermentation cycle, the particles with immobilized yeast cells were recovered, washed with double-distilled water in order to remove the glucose and calcium chloride excess, and stored at $4^{\circ} \mathrm{C}$ until use in the next fermentation cycle. Fermentative activity of the free yeast was compared with the fermentative activity of the particles with immobilized yeast cells. For this purpose, an equal amount of free yeast to that present in the immobilized particles was used for fermenting the same volume and concentration of the glucose solution under identical operating conditions.

2.2.7. Specific Productivity and the Fermentation Rate. Theoretically, the amount of ethanol formed can be calculated on the basis of the measured volume of $\mathrm{CO}_{2}$ because, under the chosen operating conditions, the alcoholic fermentation is the only metabolic activity of the yeast. The calculations are performed based on the following glucose fermentation reaction:

$$
\underset{180 \mathrm{~g}}{\mathrm{C}_{6} \mathrm{H}_{12} \mathrm{O}_{6}} \underset{2 \times 46 \mathrm{~g}}{2 \mathrm{C}_{2} \mathrm{H}_{5} \mathrm{OH}}+\underset{2 \times 22,4 \mathrm{~L}}{2 \mathrm{CO}_{2}}
$$

The specific productivity in ethanol was determined as follows: the fermentation plot: $\mathrm{CO}_{2}$ measured volume $V_{\mathrm{CO} 2}$ ( $\mathrm{ml})$ versus time $T(\mathrm{~min})$.

The amount of $\mathrm{CO}_{2}$ (in $\mathrm{ml} / \mathrm{min}$ ) is calculated from the slope of the linear section of the curve.

$$
\begin{aligned}
& \operatorname{tg} \alpha=\frac{V 2-V 1}{T 2-T 1}, \\
& \operatorname{tg} \alpha=v_{\mathrm{CO}_{2}}(\mathrm{ml} / \mathrm{min}) .
\end{aligned}
$$

The volume of gas at $0^{\circ} \mathrm{C}(273 \mathrm{~K})$ is calculated based on the volume of $\mathrm{CO}_{2}(\mathrm{ml} / \mathrm{min})$, obtained in the previous step, at the collection temperature of $30^{\circ} \mathrm{C}(303 \mathrm{~K})$. The volume of gas at $0^{\circ} \mathrm{C}$ will be expressed in $1 / \mathrm{h}$.

$$
V_{\mathrm{CO} 2}\left(0^{\circ} \mathrm{C}\right)=\frac{v_{\mathrm{CO} 2}(\mathrm{ml} / \mathrm{min}) \times 273 \times 60}{303 \times 1000}, \quad(1 / \mathrm{h}) .
$$

The flow of ethanol $\left(\mathrm{g}_{\text {ethanol }} / \mathrm{h}\right)$ is determined from the equation of the glucose fermentation:

$$
G_{v}=\frac{V_{\mathrm{CO} 2}\left(0^{\circ} \mathrm{C}\right) \times 2 \times 46}{2 \times 22,4}, \quad \mathrm{~g}_{\text {ethanol }} / \mathrm{h} .
$$

The specific productivity $\left[\mathrm{g}_{\text {ethanol }} /\left(\mathrm{h} \times \mathrm{g}_{\text {yeast }}\right)\right]$ is the ratio between the ethanol flow and the mass of dry yeast.

The amount of compressed yeast used for each sample was $1.25 \mathrm{~g}$. The total amount of dry yeast represents $30 \%$ of the total compressed yeast and is equal to $0.375 \mathrm{~g}$.

$$
P_{S}=\frac{G_{v}}{0,375}, \quad \mathrm{~g}_{\text {ethanol }} / \mathrm{h} \times \mathrm{g}_{\text {yeast cells }} .
$$

The fermentation rate is calculated as the slope of the linear portion of the glucose fermentation yield curve versus time for a period of 0 to $45 \mathrm{~min}$.

\section{Results and Discussions}

Of special interest to saccharide fermentation is the utilization of yeast with high activity along with the ability to be recovered and recycled in repeated fermentation cycles. Reusing the yeast for repeated fermentation cycles becomes possible by its encapsulation into polymeric matrices. Spherically shaped matrices are preferred, as they insure a larger contact surface (at minimum volume) with the medium in which the fermentation substrate is dissolved. The mechanical stability of the particles can be enhanced, in principle, by ionic cross-linking with bivalent metals ions to form salt bridges with the carboxylate substituent of the polysaccharide chains.

In the absence of yeast, the preliminary tests showed that the particles obtained were characterized by good mechanical stability even after a long period of storage. The presence of yeast cells in the polymer matrix, which are significantly larger than calcium ions, determines the steric hindrance which influences negatively the network formation and accordingly its mechanical stability.

Yeast cell is an electrically charged colloid and may lose the electrical load or change the sign. It is positively charged in the fermentation medium but, after a period of time, budding occurs and it becomes negatively charged. At the end of the fermentation, the electric charge of the yeast cell will become positive again $[51,52]$.

The calcium ion can adhere to the negatively charged cell plasma membrane and thus increase its stability to stressors that may occur in the fermentative processes $[41,53]$. In this manner, yeast cells could assist in the reinforcement of the network and as a consequence increase its mechanical stability. The final influence on the stability of the encapsulated particles containing yeast cells is a function of the aforementioned factors. Therefore, to better understand which factors 


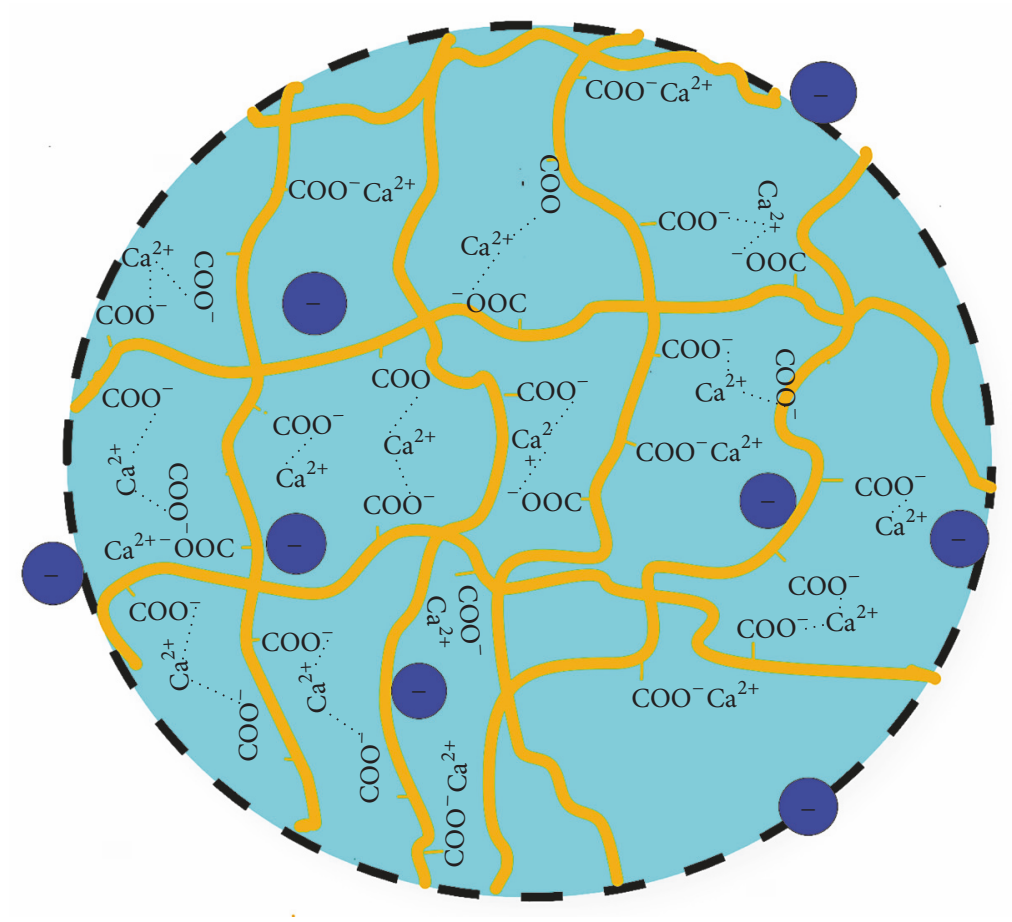

FIGURE 3: Ionically cross-linked gellan matrix containing yeast cells into the meshes.

might be predominant, a study was undertaken in order to analyze the turbidity of the supernatant by its transmittance. The cross-linking degree is reflected by the extent of turbidity and therefore different formulations containing particles with and without immobilized yeast cells were investigated at various concentrations of cations, as will be discussed below. A structure representing the gellan network with yeast cells is presented in Figure 3.

In principle, it is possible that, at the end of the extrusion process, some polymer fragments or yeast cells may not be firmly attached to the polymer network and therefore diffuse from it causing an increase of the turbidity in the crosslinking solution.

Obviously, gel strength and the characteristics of immobilized yeast cell systems are influenced by the presence of calcium ions. The alkaline ions can be introduced into the system in the preparation stage of the hot gellan solution, as well as in the precipitation stage in which the gel is dropped into the calcium chloride solution. The process requires the introduction of a small amount of $\mathrm{Ca}^{2+}$ ions to the gellan solution before extrusion in order to increase the viscosity and thus obtain spherical and stable particles in contact with the cross-linking solution in the coagulation bath during the extrusion.

3.1. Preliminary Tests for the Preparation of Hydrogel Particles. In this study, a number of preliminary tests were conducted in order to establish the parameters which have the greatest influence on the properties of the gellan particles with immobilized yeast cells. It was found that one of the parameters that influence the particles stability is the quantity of $\mathrm{Ca}^{2+}$ ions used in respect with the mass ratio of $\mathrm{CaCl}_{2}$ to polysaccharide $(\mathrm{mg} / \mathrm{g})$. For a constant quantity of gellan $(0.25 \mathrm{~g})$ and yeast $(1.25 \mathrm{~g})$, respectively, a volume of $1.25 \mathrm{~mL}$ calcium chloride solution, with different concentrations, was introduced in the hot gellan solution leading to different amounts of $\mathrm{Ca}^{2+}$ ions in the gel. It was observed that the highest value is achieved at a mass ratio of $3.3 \mathrm{mg} \mathrm{CaCl} / \mathrm{g}$ gellan; a lower value was registered at a ratio of $2.5 \mathrm{mg} \mathrm{CaCl} / g$ gellan, suggesting that a higher number of $\mathrm{Ca}^{2+}$ ions from preextrusion provide better stability for the obtained particles.

The beads containing immobilized yeast were prepared by extruding the gellan-yeast solution dropwise in the coagulation bath that contains different calcium chloride concentrations. The calcium ions in the solution interact with the carboxylic groups or with the surface of the yeast cells, leading to the formation of denser and more stable networks. Therefore, the gel beads become more firm and thus reduce the risk of disintegration but are still able to absorb water to enable swelling. Another parameter that may influence the particles stability is the $\mathrm{Ca}^{2+}$ ions concentration in the coagulation bath. Tests performed at two calcium ion concentrations in the cross-linking solution revealed that the transmittance value of the supernatant, after 2 hours of storage of the particles in this medium, was over $91.5 \%$ and this value increased with the increase of the cross-linker concentration. This effect was expected being caused by a high cross-linking degree of the particles which involves the attachment of the polysaccharide macromolecules via salt bridges at their carboxylate groups.

Another important process parameter which needs to be taken into account is the mass ratio of the material to be 
TABLE 1: Experimental program

\begin{tabular}{|c|c|c|c|}
\hline \multicolumn{2}{|c|}{ Samples* } & \multirow{2}{*}{$\begin{array}{c}\text { Concentration of } \mathrm{CaCl}_{2} \text { solution } \\
\text { before extrusion } \\
(\%, \mathrm{w} / \mathrm{v})^{* *}\end{array}$} & \multirow{2}{*}{$\begin{array}{c}\text { Concentration of } \mathrm{CaCl}_{2} \text { solution in } \\
\text { the extrusion bath } \\
(\%, \mathrm{w} / \mathrm{v})^{* * *}\end{array}$} \\
\hline Without yeast & With yeast & & \\
\hline- & PD1 & 0.1 & 2 \\
\hline P2 & PD2 & 0.3 & 2 \\
\hline- & PD3 & 0.4 & 2 \\
\hline- & PD4 & 0.5 & 2 \\
\hline P5 & PD5 & 0.3 & 3 \\
\hline P6 & PD6 & 0.3 & 4 \\
\hline
\end{tabular}

${ }^{*} 25 \mathrm{~mL}$ gellan solution, $c=1 \%(\mathrm{w} / \mathrm{v}) ;{ }^{* *} 1.25 \mathrm{~mL}$ calcium chloride solution; ${ }^{* * *} 125 \mathrm{~mL}$ calcium chloride solution.

TABLE 2: Transmittance values of the aqueous media where particles without yeast have been preserved for different time durations.

\begin{tabular}{|c|c|c|c|c|c|c|}
\hline \multirow{3}{*}{ Sample } & \multicolumn{6}{|c|}{ Transmittance (\%) } \\
\hline & \multicolumn{2}{|c|}{ In $\mathrm{CaCl}_{2}$ solution in the coagulation bath } & \multicolumn{4}{|c|}{ In double-distilled water } \\
\hline & $12 \mathrm{~h}$ & $24 \mathrm{~h}$ & $12 \mathrm{~h}$ & $24 \mathrm{~h}$ & $36 \mathrm{~h}$ & $48 \mathrm{~h}$ \\
\hline P2 & 95.6 & 95.2 & 99.1 & 98.3 & 97.5 & 95.9 \\
\hline P5 & 96.5 & 95.4 & 99.4 & 98.5 & 97.9 & 96.1 \\
\hline P6 & 96.5 & 95.6 & 99.8 & 99.2 & 98.7 & 96.3 \\
\hline
\end{tabular}

immobilized and the polymer that forms the matrix. Thus, some experiments were performed in order to establish the influence of the yeast to gellan ratio (w/w) on particles stability as evaluated indirectly by the turbidity determinations of the supernatant obtained after extrusion. The garnered results indicated that the optimized immobilization efficiency was obtained with yeast to gellan ratio of $5: 1(\mathrm{w} / \mathrm{w})$. The suspensions recovered after separation of the particles gave a high transmittance value ( $>90 \%)$. This observation indicates that the optimal ratio accords with the highest limit in which the gellan matrix can incorporate yeast cells. Above this value, the transmittance value decreases drastically having as consequence the decrease of the particle stability. Koyama and Seki [54] have described that a higher amount of yeast may lower the strength of the polymer matrix resulting from the detachment of yeast cells [54].

Based on these preliminary results, a more detailed study was conducted in order to examine the influence of the most important process parameters for the preparation of gellan particles, with and without encapsulated yeast cells. These parameters have a direct influence on the properties of the particles, such as swelling capacity in aqueous solutions, morphology, and biocatalytic activity.

The experimental program and the code for each analyzed sample are presented in Table 1.

3.2. Particles Stability and Cellular Viability. The transmittance value gives an indication of the stability of the gellan particles, with and without immobilized yeast cells.

Particle stability was evaluated based on the transmittance values of the medium in which the particles were stored over different periods of time. First medium is represented by the solution of the coagulation bath and the second medium is represented by double-distilled water. Table 2 shows transmittance values for particles without yeast cells, stored in these two media.

It was found that the particles are, in general, stable as interpreted by the high transmittance values obtained (over 95\%), as shown in Table 2. As expected, the most stable particles were those obtained in the presence of a solution of $4 \% \mathrm{CaCl}_{2}$ concentration in the coagulation bath (P6).

The transmittance values were found to decrease slightly over time for all the samples in both storage media. Moreover, particles were more stable in double-distilled water probably due to the fact that in the cross-linking solution a large quantity of the polymer fragments was removed and has not been caught in the polymeric network.

For particles with immobilized yeast cells, the turbidity was measured in the different storage media. In this case, the turbidity of the environment can be influenced not only by the polymer fragments, which are not firmly attached to the polymer network, but also by yeast cells which can diffuse from the particles. For the samples containing immobilized yeast cells, the transmittance, the concentration of cells $/ \mathrm{ml}$, and the cell viability values were determined at 12 and $24 \mathrm{~h}$.

Table 3 shows the results obtained for the particles with immobilized yeast cells at different cross-linker concentrations before extrusion.

With the exception of sample PD4 (with a $\mathrm{CaCl}_{2}$ concentration of $0.5 \%$ added before extrusion and $\mathrm{CaCl}_{2}$ concentration of $2 \%$ in the coagulation bath), high transmittance values were obtained, even higher than those recorded in the case of the particles without immobilized yeast. This is an indication that the particles with immobilized yeast cells have good stability and that the yeast cells are well embedded in the hydrogel network through interaction with $\mathrm{Ca} 2+$, this being the reason why only a very small amount of cells diffuses from the particles. Moreover, it was observed that transmittance 
TABLE 3: Influence of the $\mathrm{CaCl}_{2}$ concentration added before extrusion on the stability of the obtained particles.

\begin{tabular}{|c|c|c|c|c|c|c|c|c|c|c|c|c|}
\hline \multirow{3}{*}{ Samples } & \multicolumn{4}{|c|}{ Transmittance (\%) } & \multicolumn{4}{|c|}{$\begin{array}{l}\text { The concentration of the yeast } \\
\text { cells } / \mathrm{ml} \times 10^{4} \text { in supernatant }\end{array}$} & \multicolumn{4}{|c|}{ Cell viability, \% } \\
\hline & \multicolumn{2}{|c|}{$\begin{array}{l}\text { In } \mathrm{CaCl}_{2} \\
\text { solution in the } \\
\text { extrusion bath }\end{array}$} & \multicolumn{2}{|c|}{$\begin{array}{c}\text { In } \\
\text { double-distilled } \\
\text { water }\end{array}$} & \multicolumn{2}{|c|}{$\begin{array}{l}\text { In } \mathrm{CaCl}_{2} \\
\text { solution in the } \\
\text { extrusion bath }\end{array}$} & \multicolumn{2}{|c|}{$\begin{array}{c}\text { In } \\
\text { double-distilled } \\
\text { water }\end{array}$} & \multicolumn{2}{|c|}{$\begin{array}{l}\text { In } \mathrm{CaCl}_{2} \\
\text { solution in the } \\
\text { extrusion bath }\end{array}$} & \multicolumn{2}{|c|}{$\begin{array}{c}\text { In } \\
\text { double-distilled } \\
\text { water }\end{array}$} \\
\hline & $12 \mathrm{~h}$ & $24 \mathrm{~h}$ & $12 \mathrm{~h}$ & $24 \mathrm{~h}$ & $12 \mathrm{~h}$ & $24 \mathrm{~h}$ & $12 \mathrm{~h}$ & $24 \mathrm{~h}$ & $12 \mathrm{~h}$ & $24 \mathrm{~h}$ & $12 \mathrm{~h}$ & $24 \mathrm{~h}$ \\
\hline PD1 & 97.9 & 95.9 & 99.2 & 98.3 & 7.8 & 9.0 & 3.5 & 4.0 & 100 & 97.3 & 100 & 94.1 \\
\hline PD2 & 97.9 & 97.0 & 99.4 & 98.8 & 10.0 & 13.0 & 3.5 & 5.5 & 100 & 98.1 & 100 & 95.6 \\
\hline PD3 & 98.7 & 93.4 & 98.7 & 97.4 & 17.5 & 42.5 & 10.5 & 13.3 & 100 & 98.8 & 97.7 & 96.7 \\
\hline PD4 & 93.0 & 91.5 & 97.6 & 97 & 30.0 & 45.0 & 13.0 & 16.3 & 99.2 & 98.4 & 98.1 & 95.6 \\
\hline
\end{tabular}

TABLE 4: Influence of the $\mathrm{CaCl}_{2}$ concentrations from the cross-linking bath on the stability of the obtained particles with immobilized yeast cells.

\begin{tabular}{|c|c|c|c|c|c|c|c|c|c|c|c|}
\hline \multirow{3}{*}{ Samples } & \multicolumn{5}{|c|}{ Transmittance (\%) } & $\begin{array}{l}\text { The concentration of } \\
\text { the yeast cells } / \mathrm{ml} \times\end{array}$ & \multicolumn{5}{|c|}{ Cell viability, \% } \\
\hline & \multicolumn{2}{|c|}{$\begin{array}{c}\text { In } \mathrm{CaCl}_{2} \text { solution } \\
\text { in the extrusion } \\
\text { bath }\end{array}$} & \multicolumn{3}{|c|}{ In double-distilled water } & \multirow{2}{*}{$\begin{array}{l}\text { In } \mathrm{CaCl}_{2} \text { solution in } \\
\text { the extrusion bath } \\
\qquad 24 \mathrm{~h}\end{array}$} & \multirow{2}{*}{$\begin{array}{l}\text { In double- } \\
\text { distilled } \\
\text { water } \\
12 \mathrm{~h}\end{array}$} & \multirow{2}{*}{$\begin{array}{c}\text { In } \mathrm{CaCl}_{2} \\
\text { solution in } \\
\text { the } \\
\text { extrusion } \\
\text { bath } \\
36 \mathrm{~h}\end{array}$} & \multicolumn{3}{|c|}{$\begin{array}{l}\text { In double-distilled } \\
\text { water }\end{array}$} \\
\hline & $12 \mathrm{~h}$ & $24 \mathrm{~h}$ & $12 \mathrm{~h}$ & $24 \mathrm{~h}$ & $36 \mathrm{~h}$ & & & & $24 \mathrm{~h}$ & $24 \mathrm{~h}$ & $36 \mathrm{~h}$ \\
\hline PD2 & 96.8 & 96.0 & 99.3 & 98.3 & 97.8 & 35.0 & 3.3 & 15.0 & 97.9 & 97.0 & 95.2 \\
\hline PD5 & 97.0 & 96.1 & 99.4 & 98.7 & 98.3 & 26.5 & 3.3 & 13.8 & 97.2 & 97.0 & 94.8 \\
\hline PD6 & 97.5 & 96.2 & 99.4 & 98.8 & 98.5 & 20.0 & 3.0 & 9.75 & 96.4 & 93.9 & 92.9 \\
\hline
\end{tabular}

TABLE 5: Influence of the alcoholic medium on the stability and viability of the yeast cells immobilized in gellan particles.

\begin{tabular}{|c|c|c|c|c|c|c|c|c|c|c|c|c|}
\hline \multirow[t]{2}{*}{ Samples } & \multicolumn{4}{|c|}{ Transmittance (\%) } & \multicolumn{4}{|c|}{$\begin{array}{l}\text { The concentration of the } \\
\text { yeast cells } / \mathrm{ml} \times 10^{4} \text { in } \\
\text { supernatant }\end{array}$} & \multicolumn{4}{|c|}{ Cell viability, \% } \\
\hline & $12 \mathrm{~h}$ & $36 \mathrm{~h}$ & $60 \mathrm{~h}$ & $84 \mathrm{~h}$ & $12 \mathrm{~h}$ & $36 \mathrm{~h}$ & $60 \mathrm{~h}$ & $84 \mathrm{~h}$ & $12 \mathrm{~h}$ & $36 \mathrm{~h}$ & $60 \mathrm{~h}$ & $84 \mathrm{~h}$ \\
\hline PD2 & 97.8 & 96.6 & 95.8 & 94.7 & 16.3 & 20.0 & 25.8 & 38.3 & 98.5 & 96.4 & 97.2 & 96.8 \\
\hline PD5 & 98.4 & 97.4 & 96.8 & 96.1 & 8.8 & 12.0 & 14.3 & 21.3 & 97.2 & 96.0 & 95.0 & 94.4 \\
\hline PD6 & 98.7 & 97.8 & 97.3 & 96.5 & 8.3 & 10.5 & 11.0 & 18.8 & 97.1 & 95.5 & 95.7 & 93.8 \\
\hline
\end{tabular}

values decrease slightly with storage duration in aqueous media and that the cells concentration increased slightly as a function of time. Furthermore, it should be mentioned that the cell viability is very high even after more than 24 hours of storage in aqueous medium with values generally higher than 95\%.

Similar results were also obtained for the particles with immobilized yeast cells prepared at the different cross-linking agent concentrations in the coagulation bath, as indicated in Table 4.

As observed from Table 4, the stability of the particles with immobilized yeast cells remained higher in comparison with those without yeast cells, and it slightly increased with $\mathrm{Ca}^{2+}$ ion concentration. By comparing sample PD2 to sample PD6, it occurs that the concentration of cells which diffused from the polymeric matrix in supernatant decreased with the amount of cross-linking. Furthermore, the cell viability slightly decreased, but the values were still $>90 \%$. Lower cell concentrations were observed in distilled water due to diffusion of some of the cells over the 24 hours in $\mathrm{CaCl}_{2}$ solution in the coagulation bath prior to the transfer in distilled water.

The use of immobilized cells in successive fermentation cycles involves their storage for long periods of time in an alcoholic medium which can affect the cells integrity.

Upon examination of the results presented in Table 5, it can be observed that the transmittance values of the alcohol medium in which the particles were suspended are still high even after 84 hours, with the highest values being determined for the particles with the highest level of cross-linking (PD6). 


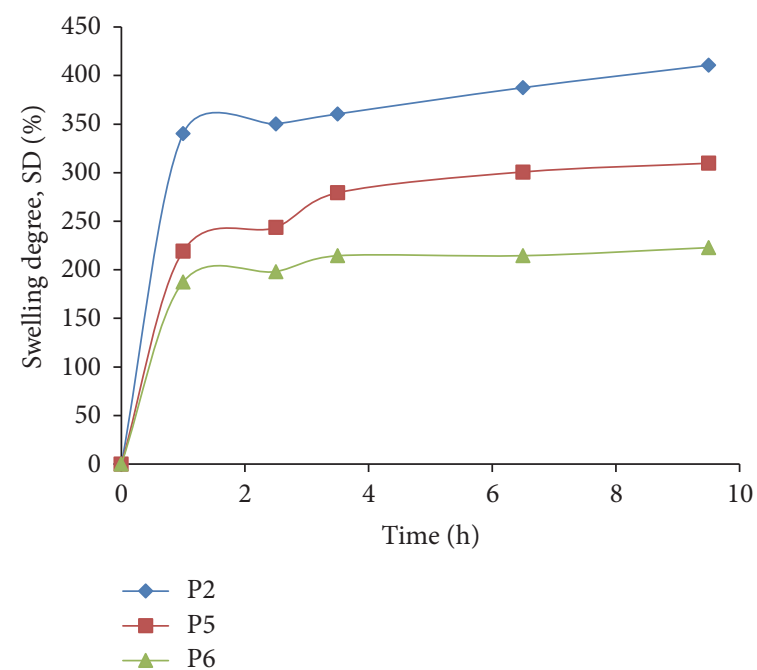

(a)

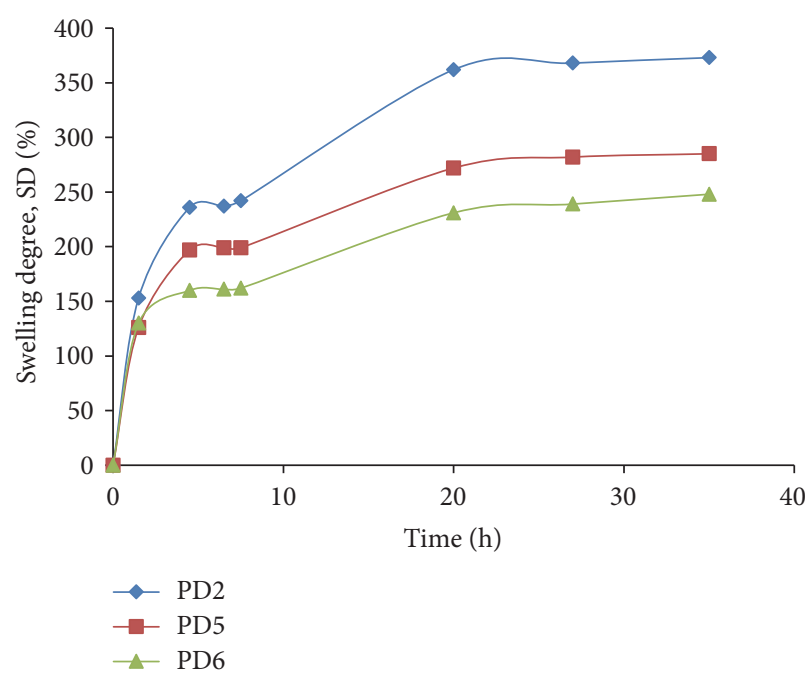

(b)

FIGURE 4: Variation of the swelling degree, in water, in time for gellan particles without (a) and with (b) yeast cells obtained in different extrusion conditions.

Moreover, it was observed that when the cell concentration in the supernatant was low, the cell viability was maintained at a high level.

In conclusion, the particles with immobilized yeast cells are stable in alcoholic medium, which is a requirement for their use in repeated fermentation cycles.

3.3. Swelling Degree. Gellan particles containing yeast cells can be considered as microbioreactors. The substrate fermentation, represented by glucose, occurs as a result of the monosaccharide diffusing into the polymer matrix, where it comes into contact with the yeast cells.

The substrate diffusion into the particles is influenced by the ability to swell in aqueous media and especially by the cross-linking degree.

For this study, it was considered useful to evaluate the ability of the obtained particles to swell in water in order to correlate this characteristic with other properties, including the fermentation capacity.

Figure 4 shows the variation of SD\% in time for gellan particles with and without the presence of yeast cells obtained with different $\mathrm{CaCl}_{2}$ solution concentrations in the coagulation bath. Data in Figure 4 show high values for the swelling degree in water which is strongly indicative of the particles possessing hydrogel character.

From Figure 4, it appears that the maximum swelling degree and the swelling rate decrease with the increase of the cross-linking agent concentration in the coagulation bath. It can be noted, however, that constantly lower values were observed for particles containing yeast cells (Figure 4(b)) compared with those without yeast (Figure 4(a)). This expected effect is a consequence of direct contribution of negatively charged yeast cells in their reaction with $\mathrm{Ca}^{2+}$. Also, the maximum SD\% values for particles with immobilized yeast cells decrease when the cross-linking agent concentration increases.
These results are in concordance with the stability of the particles, evaluated indirectly by the transmittance values of aqueous media in which they were suspended. Particles characterized by a lower swelling degree showed higher transmittance values both when suspended in the supernatant (in the coagulation bath) and in water or in aqueous alcohol solution.

3.4. Morphological and Structural Analysis by SEM. Important information for the particles morphology, with and without yeast cells, was obtained by scanning electron microscopy (SEM). SEM micrographs were performed in the cross section of the dry and swollen in water samples without immobilized yeast cells (P2) and with immobilized yeast cells (PD2), as depicted in Figure 5.

From Figure 5, it can be observed that the particles without yeast cells (a) have a porous morphology when they are swollen, while the particles with immobilized yeast cells (b) take a more compact morphology with the cells being well embedded in the polymer matrix due to the salt-bridge binding with the cross-linking agent having the tendency to form agglomerates. Particles morphology is in concordance with their swelling behavior, which accords with the lower values of the maximum swelling degree for particles with immobilized yeast cells. An even larger distribution of the yeast cells was observed in the polymer matrix (PD2) in the dry state where the polymer covers each of the cells.

From the SEM results, it appears that gellan particles contain a large number of yeast cells which are capable of being used in repeated fermentation processes as microbioreactors.

3.5. The Fermentative Activity of the Gellan Particles with Immobilized Yeast Cells. Other important parameters which are worth to be investigated are the capacity of glucose fermentation in the presence of gellan particles with immobilized yeast cells obtained under different conditions and the 

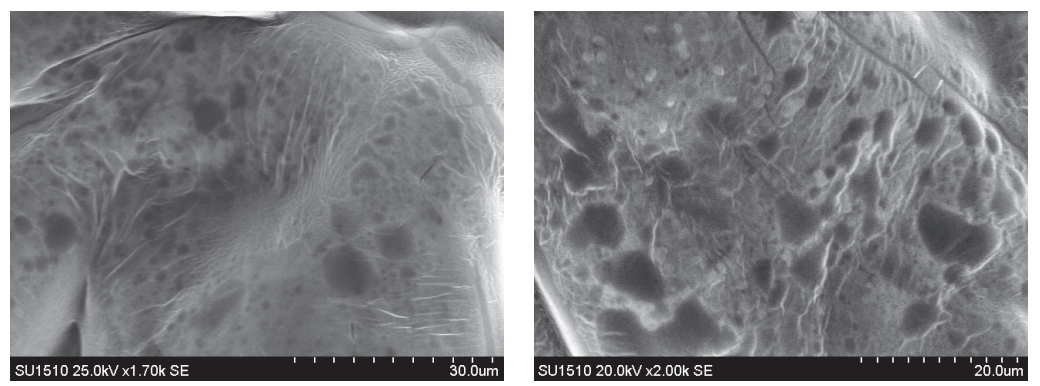

(a) P2 swollen particles in water
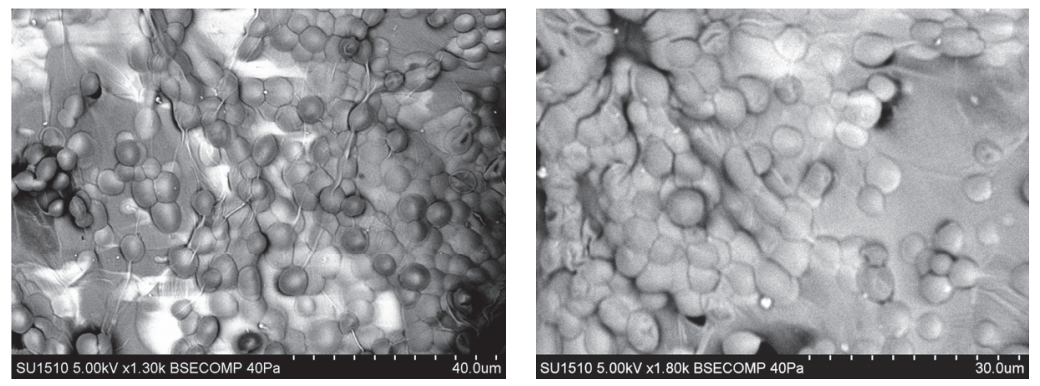

(b) PD2 swollen particles in water
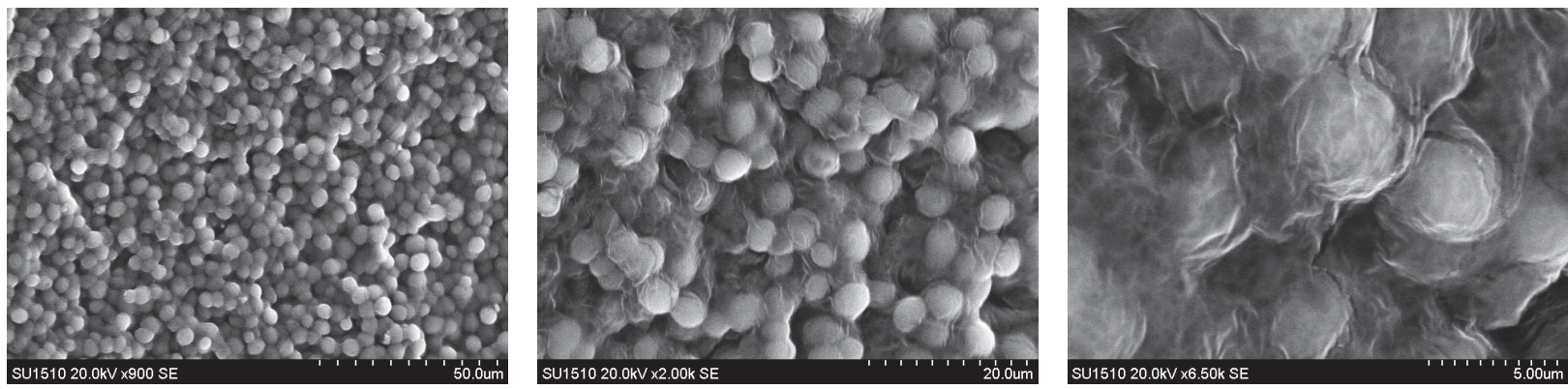

(c) PD2 dry particles

FIGURE 5: SEM images for P2 and PD2 swollen particles in water or in dry state.

evaluation of the possibility of these particles to be reused in repeated fermentation cycles.

The results shown in Figure 6 illustrate the variation of yield in glucose fermentation as a function of time, for 5 fermentation cycles, in the presence of particles with immobilized yeast cells, compared to the fermentation of free yeast cells (samples PD2 and PD3 were chosen because they have different degrees of cross-linking).

From Figure 6, it can be observed that, after 255 minutes, the fermentation yields for both types of particles were higher than those obtained for free yeast. A higher fermentation yield was obtained for PD2 particles, when compared to PD5, even after 5 cycles of fermentation (Figure 6). A plausible explanation is that there are different cross-linking degrees in the two particle types, with PD5 sample having a higher crosslinking degree than PD2 sample. Obviously, the fermentation process is catalyzed by the yeast cells from the polymeric matrix and only a very small percentage of those will be from the fermentation medium, in which a few cells have diffused. The substrate, represented by the glucose solution, diffuses into the hydrogel matrix based on gellan and reaches the immobilized yeast cells, which will catalyze the process.

The intensity of the diffusion is determined by the crosslinking degree of the polymeric matrix (glucose concentration in the fermentation medium is the same in both particles types). It appeared that the diffusion was more intense for PD2, which explains higher fermentation yields, in perfect concordance with the results obtained regarding the swelling degree and the transmittance values of the solutions in which particles were suspended.

Previous research has shown that for the alginate particles ionically cross-linked with $\mathrm{CaCl}_{2}$ an optimal concentration of $2 \%$ of $\mathrm{CaCl}_{2}$ in the extrusion bath was used in order to obtain an optimal fermentation yield. A lower degree of cross-linking leads to a higher mass transfer due to diffusion of the substrate to the yeast cells within the matrix [15]. The limitation of mass transfer is a problem in the cells immobilization by the inclusion method as cells may retain high viability and high productivity in ethanol only if there is achieved an efficient exchange between nutrients and particles [55]. However, the most important finding of this 


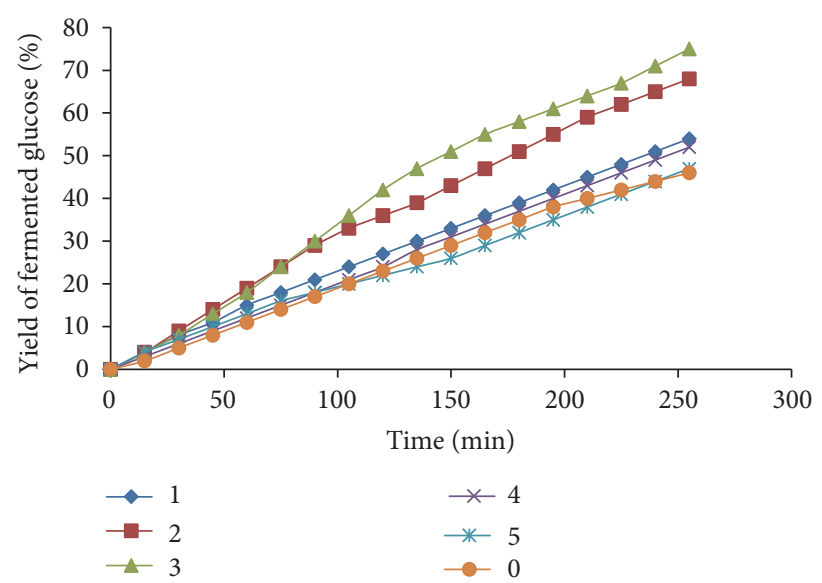

(a)

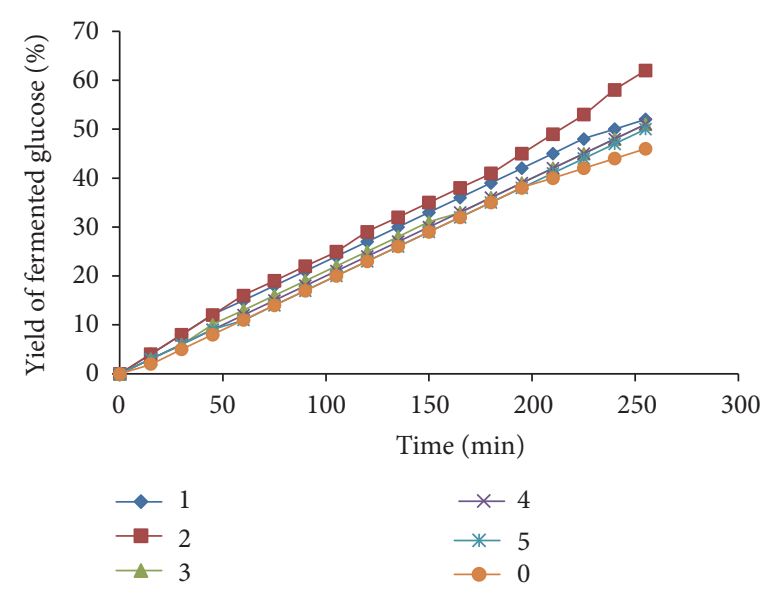

(b)

Figure 6: Variation in time of the yield in fermented glucose for the first 5 fermentation cycles (curve 0-free yeast cells), compared with the yield obtained in free yeast fermentation for particles PD2 (a) and PD5 (b).

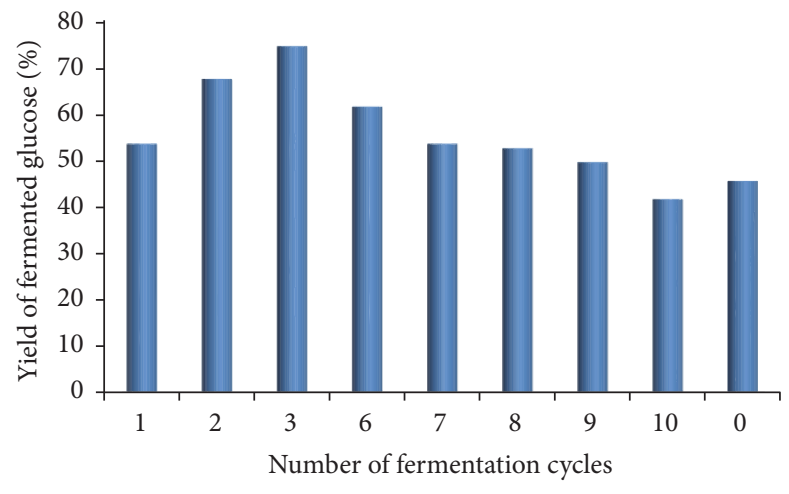

(a)

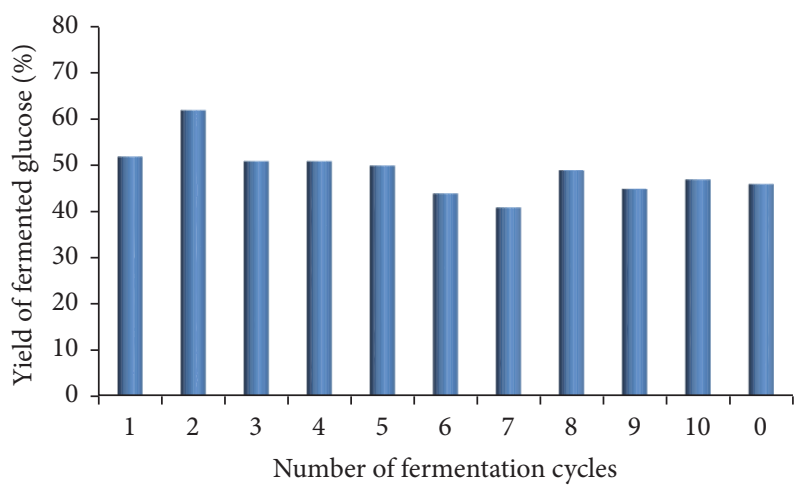

(b)

FIGURE 7: Yield values in fermented glucose (after 255 minutes) for the samples PD2 (a) and PD5 (b) as a function of the fermentation cycles.

study is that the particles can be used in repeated fermentation cycles after separation by filtration and washing with double-distilled water. Figure 6 presents yields obtained after 5 fermentation cycles. A surprising observation is that the yields for PD2 are higher for the 2nd and 3rd fermentation cycles than for the first cycle. This phenomenon was also observed for the 2nd cycle of sample PD3. The explanation may be that the cells from the polymer matrix have known a multiplication process after the first cycle. For both particle types, the fermentation was continued until the 10th cycle and the maximum yields achieved were compared, as shown in Figure 7.

For PD3 sample, it can be considered that the yield was relatively constant for all 10 cycles (Figure $7(\mathrm{~b})$ ), while PD2 sample is characterized by some surprising fluctuations in yield. Similar results, regarding the variation of the fermentation yield, were also observed by other researchers. For example, Mariam et al. [56] obtained microbioreactors based on sodium alginate with immobilized yeast cells by ionic cross-linking in the presence of calcium chloride which were tested in terms of fermentative activity. For these systems, the maximum number of fermentation cycles was 6 and the maximum increase of the fermentation yield was observed for the 4 th cycle after which the yield drops sharply. The explanation given by these authors for this behavior was that the microbioreactors become unstable after the 4 th fermentation cycle and change shape [56].

The fermentation yield for sample PD3 is almost constant as the particles cross-linking degree is higher compared to sample PD2 and the particles are more stable.

It is necessary to have an efficient exchange of nutrients between the fermentation medium and particles for that yeast cells inside the particles can perform essential physiological functions and also achieve optimal efficiency in the fermentation process.

However, it is worth mentioning that, regardless of the number of fermentation cycles for both samples, the fermentation yield was higher than or at least equal to the yield recorded for fermentation using free yeast cells.

In order to determine if the particles are stable, in the fermentation medium after each cycle, the number of yeast cells in the medium and their amount were determined on the basis of the calibration curve (Figure 2). Knowing the initial amount of yeast cells which was immobilized, which is equal 
TABLE 6: Theoretical concentration of yeast cells in the PD5 particles after each fermentation cycle.

\begin{tabular}{lcc}
\hline $\begin{array}{l}\text { Fermentation } \\
\text { cycle }\end{array}$ & $\begin{array}{c}\text { The yeast cells quantity } \\
(\mathrm{g}) \text { in } 50 \text { ml solution } \\
\text { (from the fermentation } \\
\text { bath) } \times 10^{4}\end{array}$ & $\begin{array}{c}\text { The theoretical yeast } \\
\text { cells quantity that } \\
\text { remained in the } \\
\text { particles }(\mathrm{g})\end{array}$ \\
\hline I & 1.667 & 0.374 \\
II & 3.196 & 0.374 \\
III & 0.835 & 0.374 \\
IV & 0.879 & 0.374 \\
V & 0.556 & 0.374 \\
VI & 1.019 & 0.374 \\
VII & 1.714 & 0.374 \\
VIII & 0.602 & 0.373 \\
IX & 0.509 & 0.373 \\
X & 0.162 & 0.373 \\
\hline
\end{tabular}

TABLE 7: Cell viability and cells amount in one gram of particles determined according to various repeated fermentation cycles for sample PD2.

\begin{tabular}{lccc}
\hline $\begin{array}{l}\text { Fermentation } \\
\text { cycle }\end{array}$ & $\begin{array}{c}\text { Cells number/g } \\
\times 10^{8}\end{array}$ & $\begin{array}{c}\text { Cells amount/g } \\
\text { particles, mg }\end{array}$ & Cell viability, \% \\
\hline 0 & 4.8 & 17.81 & 94.2 \\
I & 5.9 & 21.86 & 94.9 \\
II & 6.0 & 21.86 & 95.3 \\
IV & 6.4 & 23.71 & 92.2 \\
VIII & 7.4 & 27.78 & 90.2 \\
IX & 6.4 & 23.71 & 90.4 \\
X & 6.0 & 22.04 & 90.3 \\
\hline
\end{tabular}

to $0.375 \mathrm{~g}$ ( $30 \%$ of the $1.25 \mathrm{~g}$ ), it is possible to calculate the theoretical amount of cells from the particles by subtracting the amount of cells that can be found in the fermentation medium after each cycle. The amount of cell proliferating within the particles has not been taken into account. The previous test was carried out just to demonstrate that the cells are firmly attached to the polymer network and that they do not diffuse in large numbers in the fermentation medium even after repeated fermentation cycles.

For sample PD5, these results are presented in Table 6.

Table 6 shows that the number of diffusing cells from the particles is very small compared to the theoretical number of cells that remain trapped in the polymer network. This is a clear indication that particles are stable and can be used in several repeated fermentation cycles.

3.6. Assessment of Cell Viability and Cell Amount from the Particles after Each Fermentation Cycle. Keeping the cell viability during the fermentation process is a prerequisite for the use of particles in several fermentation cycles. In Table 7 are provided the data concerning the cell viability for sample PD2 as a typical example.

From Table 7, it appears that the cell viability tends to decrease as a function of the fermentation cycles. However,

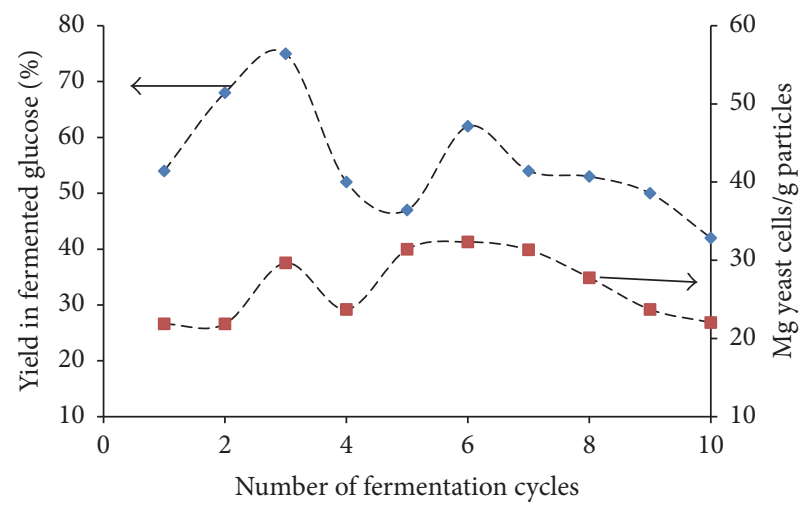

FIGURE 8: Variation of the amount of cells/g of particles as a function of the fermentation cycles number for sample PD2 compared to the maximum yield obtained after each fermentation cycle.

a slight increase in cell viability was observed in cycle 2 probably due to cell proliferation. These high values for cell viability show that the polymer matrix protects the yeast cells from the factors that may affect the cell growth. Figure 8 presents the evolution of the fermentation yield and the amount of cells from the particles after each fermentation cycle.

Figure 8 proves that the yeast cells proliferate within the gellan particles. There is a good agreement between the amount of the cells from the particles and the variation of the fermentation yield. After six fermentation cycles, the yield values begin to decrease in concordance with the amount of yeast cells from the particles.

These results show that the particles cross-linking degree is optimal and thus it provides adequate particle porosity necessary for an efficient exchange of nutrients between the fermentation medium and the cells within the particles.

Cells can proliferate within the polymer matrix and the obtained fermentation yields are optimum and comparable to those obtained from the fermentation of free yeast. Moreover, the particles can be easily recovered from the fermenter and can be reused in several fermentation cycles.

3.7. Specific Productivity and Fermentation Rate. It was possible to estimate the process rate values, expressed as \% of glucose conversion per minute, as well as the values for the specific ethanol productivity $\left[g_{\text {ethanol }} /\left(\mathrm{h} \times \mathrm{g}_{\text {yeast }}\right)\right]$, in the immobilized particles) from the linear zone of the kinetic plots of the fermentation process. These values are given in Table 8 .

The fermentation rate follows a similar trend as the fermentation yield for both samples for all 10 cycles. Interestingly, the value for specific productivity is constant for most of the fermentation cycles for both types of immobilized particles, and it is comparable or even superior to that obtained from the fermentation of free yeast cells.

\section{Conclusions}

Gellan is a convenient matrix for the yeast cells immobilization, because it can be easily cross-linked with $\mathrm{Ca}^{2+}$ 
TABLE 8: Fermentation rate values and the specific ethanol productivity for samples PD2 and PD3 as a function of the fermentation cycle.

\begin{tabular}{|c|c|c|c|c|}
\hline \multirow[t]{2}{*}{ Fermentation cycle } & \multicolumn{2}{|c|}{$\begin{array}{c}\text { Fermentation rate, ri, } \\
(\% \text { glucose conversion } / \mathrm{min})\end{array}$} & \multicolumn{2}{|c|}{$\begin{array}{l}\text { Specific productivity in ethanol } \\
{\left[\mathrm{g}_{\text {ethanol }} /\left(\mathrm{h} \times \mathrm{g}_{\text {yeast }}\right)\right]}\end{array}$} \\
\hline & PD2 & PD3 & PD2 & PD3 \\
\hline I & 0.24 & 0.27 & 0.60 & 0.60 \\
\hline II & 0.31 & 0.27 & 0.97 & 0.80 \\
\hline III & 0.29 & 0.22 & 1.07 & 0.60 \\
\hline IV & 0.20 & 0.20 & 0.60 & 0.60 \\
\hline V & 0.22 & 0.20 & 0.60 & 0.60 \\
\hline VI & 0.27 & 0.20 & 0.83 & 0.60 \\
\hline VII & 0.24 & 0.20 & 0.60 & 0.60 \\
\hline VIII & 0.22 & 0.16 & 0.60 & 0.60 \\
\hline IX & 0.18 & 0.16 & 0.60 & 0.50 \\
\hline $\mathrm{X}$ & 0.20 & 0.20 & 0.60 & 0.60 \\
\hline Free yeast & \multicolumn{2}{|c|}{0.07} & \multicolumn{2}{|c|}{0.60} \\
\hline
\end{tabular}

ions leading to stable particles both in aqueous media and in alcoholic solutions. This feature allows furthermore the use of the obtained microbioreactors in a large number of fermentation cycles. The particles stability is sparsely influenced by the amount of the cross-linking agent before extrusion and in the coagulation bath. However, the crosslinking agent's concentration was found to influence the behavior of particles in aqueous media by affecting the degree of the cross-linking and consequently the diffusion of the substrate into the immobilized yeast cells. The particles without yeast cells showed a slightly porous morphology, whereas those containing yeast cells are more compact probably due to their involvement in the cross-linking. This study has demonstrated the viability of bioreactors based on cross-linked gellan which can be used for a large number of fermentation cycles without losing their biocatalytic activity and also ensuring high values of specific productivity in comparison with the use of free yeast cells. Finally, this study highlights the feasibility of using immobilized yeast cells entrapped in gellan matrix in continuous fermentation processes.

\section{Conflicts of Interest}

The authors declare that they have no conflicts of interest.

\section{Acknowledgments}

This work was supported by the strategic Grant POSDRU/159/1.5/S/133652, cofinanced by the European Social Fund within the Sectorial Operational Program Human Resources Development 2007-2013.

\section{References}

[1] R. Willaert and V. Nedovic, "Primary beer fermentation by immobilised yeast - A review on flavour formation and control strategies," Journal of Chemical Technology and Biotechnology, vol. 81, no. 8, pp. 1353-1367, 2006.
[2] A. Poreda, T. Tuszyński, M. Zdaniewicz, P. Sroka, and M. Jakubowski, "Support materials for yeast immobilization affect the concentration of metal ions in the fermentation medium," Journal of the Institute of Brewing, vol. 119, no. 3, pp. 164-171, 2013.

[3] F. Talebnia and M. J. Taherzadeh, "Physiological and morphological study of encapsulated Saccharomyces cerevisiae," Enzyme and Microbial Technology, vol. 41, no. 6-7, pp. 683-688, 2007.

[4] W. Yu, H. Song, G. Zheng, X. Liu, Y. Zhang, and X. Ma, "Study on membrane characteristics of alginate-chitosan microcapsule with cell growth," Journal of Membrane Science, vol. 377, no. 1-2, pp. 214-220, 2011.

[5] J. N. De Vasconcelos, C. E. Lopes, and F. P. De França, "Continuous ethanol production using yeast immobilized on sugar-cane stalks," Brazilian Journal of Chemical Engineering, vol. 21, no. 3, pp. 357-365, 2004.

[6] P. Bangrak, S. Limtong, and M. Phisalaphong, "Continuous ethanol production using immobilized yeast cells entrapped in loofareinforced alginate carriers," Brazilian Journal of Microbiology, vol. 42, no. 2, pp. 676-684, 2011.

[7] C. T. H. Tran, N. Nosworthy, M. M. M. Bilek, and D. R. McKenzie, "Covalent immobilization of enzymes and yeast: towards a continuous simultaneous saccharification and fermentation process for cellulosic ethanol," Biomass and Bioenergy, vol. 81, pp. 234-241, 2015.

[8] S. C. S. Martins, C. M. Martins, L. M. C. G. Fiúza, and S. T. Santaella, "Immobilization of microbial cells: a promising tool for treatment of toxic pollutants in industrial wastewater," African Journal of Biotechnology, vol. 12, pp. 4412-4418, 2013.

[9] C. Tomaro-Duchesneau, S. Saha, M. Malhotra, I. Kahouli, and S. Prakash, "Microencapsulation for the therapeutic delivery of drugs, live mammalian and bacterial cells, and other biopharmaceutics: current status and future directions," Journal of Pharmaceutics, vol. 2013, Article ID 103527, 19 pages, 2013.

[10] V. Ivanova, P. Petrova, and J. Hristov, "Application in the ethanol fermentation of immobilized yeast cells in matrix of alginate/magnetic nanoparticles, on chitosan-magnetite microparticles and cellulose-coated magnetic nanoparticles," International Review of Chemical Engineering, vol. 3, pp. 289-299, 2011. 
[11] G. M. Walker and G. G. Stewart, "Saccharomyces cerevisiae in the production of fermented beverages," Beverages, vol. 2, no. 4, p. 30, 2016.

[12] Y. Kourkoutas, A. Bekatorou, I. M. Banat, R. Marchant, and A. A. Koutinas, "Immobilization technologies and support materials suitable in alcohol beverages production: a review," Food Microbiology, vol. 21, no. 4, pp. 377-397, 2004.

[13] Y. Kourkoutas, V. Manojlovic, and V. A. Nedovic, "Immobilization ofmicrobial cells for alcoholic and malolactic fermentation of wine and cider," in Encapsulation Technologies for Active Food Ingredients and Food Processing, V. A. Nedovic and N. J. Zuidam, Eds., pp. 327-343, Springer, London, UK, 2010.

[14] A. Martinez, G. Vivas, and M. Quicazan, "Evaluation of alcoholic fermentation during the production of mead using immobilized cells in kappa-carrageenan," Chemical Engineering Transactions, vol. 49, pp. 19-24, 2016.

[15] I. Călinescu, P. Chipurici, A. Trifan, and C. Bădoiu, "Immobilisation of Saccharomyces cerevisiae for the production of bioethanol," UPB Scientific Bulletin, vol. 74, pp. 33-40, 2012.

[16] G. Najafpour, H. Younesi, and K. S. Ku Ismail, "Ethanol fermentation in an immobilized cell reactor using Saccharomyces cerevisiae," Bioresource Technology, vol. 92, no. 3, pp. 251-260, 2004.

[17] S. H. Ching, N. Bansal, and B. Bhandari, "Alginate gel particles-a review of production techniques and physical properties," Critical Reviews in Food Science and Nutrition, vol. 57, no. 6, pp. 1133-1152, 2015.

[18] T. Andersen, P. Auk-Emblem, and M. Dornish, “3D cell culture in alginate hydrogels," Microarrays, vol. 4, no. 2, pp. 133-161, 2015.

[19] A. Idris and W. Suzana, "Effect of sodium alginate concentration, bead diameter, initial $\mathrm{pH}$ and temperature on lactic acid production from pineapple waste using immobilized Lactobacillus delbrueckii," Process Biochemistry, vol. 41, no. 5, pp. 1117-1123, 2006.

[20] E. I. Paramera, V. T. Karathanos, and S. J. Konteles, "Yeast cells and yeast-based materials for microencapsulation," in Microencapsulation in the Food Industry, A. G. Gaonkar, N. Vasisht, A. R. Khare, and R. Sobel, Eds., pp. 267-281, Elsevier, 2014.

[21] V. Nedovic, A. Kalusevic, V. Manojlovic, S. Levic, and B. Bugarski, "An overview of encapsulation technologies for food applications," Procedia Food Science, vol. 1, pp. 1806-1815, 2011.

[22] E. P. Bardi and A. A. Koutinas, "Immobilization of yeast on delignified cellulosic material for room temperature and lowtemperature wine making," Journal of Agricultural and Food Chemistry, vol. 42, no. 1, pp. 221-226, 1994.

[23] C. Ibarguren, C. R. F. Grosso, M. C. Apella, and M. C. Audisio, "Anti-Listeria monocytogenes activity of enterocins microencapsulated by ionic gelation," Food Hydrocolloids, vol. 29, no. 1, pp. 21-26, 2012.

[24] H. T. Fabich, S. J. Vogt, M. L. Sherick et al., "Microbial and algal alginate gelation characterized by magnetic resonance," Journal of Biotechnology, vol. 161, no. 3, pp. 320-327, 2012.

[25] V. Nedovic, R. Willaert, I. Leskošek-Čukalović, B. Obradović, and B. Bugarski, "Beer production using immobilised cells," in Applications of Cell Immobilisation Biotechnology, V. Nedovic and R. Willaert, Eds., pp. 259-273, Springer, Netherlands, 2005.

[26] J. C. Duarte, J. A. R. Rodrigues, P. J. S. Moran, G. P. Valença, and J. R. Nunhez, "Effect of immobilized cells in calcium alginate beads in alcoholic fermentation," AMB Express, vol. 3, pp. 1-8, 2013.
[27] H. N. Öztop, A. Y. Öztop, E. Karadağ, Y. Işikver, and D. Saraydin, "Immobilization of Saccharomyces cerevisiae on to acrylamidesodium acrylate hydrogels for production of ethyl alcohol," Enzyme and Microbial Technology, vol. 32, no. 1, pp. 114-119, 2003.

[28] S. H. Hong, M. Shin, J. Lee et al., "Stable alginate gel prepared by linkage exchange from ionic to covalent bonds," Advanced Healthcare Materials, vol. 5, no. 1, pp. 75-79, 2016.

[29] G. Xu, J. Li, H. Cui, Q. He, Z. Zhang, and X. Zhan, "Biotemplated fabrication of porous alumina ceramics with controllable pore size using bioactive yeast as pore-forming agent," Ceramics International, vol. 41, no. 5, pp. 7042-7047, 2015.

[30] P. Loukatos, M. Kiaris, I. Ligas et al., "Continuous wine making by $\gamma$-alumina-supported biocatalyst," Applied Biochemistry and Biotechnology, vol. 89, no. 1, pp. 1-14, 2000.

[31] A. Ursoiu, C. Paul, T. Kurtán, and F. Péter, "Sol-gel entrapped candida antarctica lipase B-A biocatalyst with excellent stability for kinetic resolution of secondary alcohols," Molecules, vol. 17, no. 11, pp. 13045-13061, 2012.

[32] G. Aykut, V. N. Hasirci, and G. Alaeddinoglu, "Immobilization of yeast cells in acrylamide gel matrix," Biomaterials, vol. 9, no. 2, pp. 168-172, 1988.

[33] R. A. Peinado, J. J. Moreno, J. M. Villalba, J. A. González-Reyes, J. M. Ortega, and J. C. Mauricio, "Yeast biocapsules: a new immobilization method and their applications," Enzyme and Microbial Technology, vol. 40, no. 1, pp. 79-84, 2006.

[34] E. Callone, R. Campostrini, G. Carturan, A. Cavazza, and R. Guzzon, "Immobilization of yeast and bacteria cells in alginate microbeads coated with silica membranes: procedures, physico-chemical features and bioactivity," Journal of Materials Chemistry, vol. 18, no. 40, pp. 4839-4848, 2008.

[35] C. M. S. G. Baptista, J. M. A. Cóias, A. C. M. Oliveira et al., "Natural immobilisation of microorganisms for continuous ethanol production," Enzyme and Microbial Technology, vol. 40, no. 1, pp. 127-131, 2006.

[36] M. A. O’Neill, R. R. Selvendran, and V. J. Morris, "Structure of the acidic extracellular gelling polysaccharide produced by Pseudomonas elodea," Carbohydrate Research, vol. 124, no. 1, pp. 123-133, 1983.

[37] A. Mantaluta, D. Cojocaru, C. Savin, and R. Pasa, "The testing of some organic supports for yeasts immobilization technology used in sparkling wine production, Annnals of the "Alexandru Ioan Cuza" University," Genetics and Molecular Biology, vol. 12, pp. 81-85, 2012.

[38] S. M. Tan, P. W. S. Heng, and L. W. Chan, "Development of reusable yeast-gellan gum micro-bioreactors for potential application in continuous fermentation to produce bio-ethanol," Pharmaceutics, vol. 3, no. 4, pp. 731-744, 2011.

[39] M. S. Cyert and C. C. Philpott, "Regulation of cation balance in Saccharomyces cerevisiae," Genetics, vol. 193, no. 3, pp. 677-713, 2013.

[40] P. Aleksander, A. Piotr, T. Tadeusz, and M. Makarewicz, "Accumulation and release of metal ions by brewer's yeast during successive fermentations," Journal of the Institute of Brewing, vol. 115 , no. 1, pp. 78-83, 2009.

[41] H. O. Udeh and T. E. Kgatla, "Role of magnesium ions on yeast performance during very high gravity fermentation," Journal of Brewing and Distilling, vol. 4, no. 2, pp. 19-45, 2013.

[42] S. Liu, Y. Hou, W. Liu, C. Lu, W. Wang, and S. Sun, "Components of the calcium-calcineurin signaling pathway in fungal cells and their potential as antifungal targets," Eukaryotic Cell, vol. 14, no. 4, pp. 324-334, 2015. 
[43] A. J. Dobbs, M. Peleg, R. E. Mudgett, and R. Rufner, "Some physical characteristics of active dry yeast," Powder Technology, vol. 32, no. 1, pp. 63-69, 1982.

[44] G. Reed and T. W. Nagodawithana, "Baker's yeast production," in Yeast Technology, G. Reed, Ed., pp. 261-314, Springer, Netherlands, 1990.

[45] E. Potthoff, O. Guillaume-Gentil, D. Ossola et al., "Rapid and serial quantification of adhesion forces of yeast and mammalian cells," PLoS ONE, vol. 7, no. 12, article e52712, 2012.

[46] F. Randez-Gil, I. Córcoles-Sáez, and J. A. Prieto, "Genetic and phenotypic characteristics of baker's yeast: relevance to baking," Annual Review of Food Science and Technology, vol. 4, no. 1, pp. 191-214, 2013.

[47] F. M. Klis, C. G. de Koster, and S. Brul, "Cell wall-related bionumbers and bioestimates of Saccharomyces cerevisiae and Candida albicans," Eukaryotic Cell, vol. 13, no. 1, pp. 2-9, 2014.

[48] Y. Lin, W. Zhang, C. Li, K. Sakakibara, S. Tanaka, and H. Kong, "Factors affecting ethanol fermentation using Saccharomyces cerevisiae BY4742," Biomass and Bioenergy, vol. 47, pp. 395-401, 2012.

[49] V. Stehlik-Thomas, V. G. Zetic, D. Stanzer, S. Grba, and N. Vahcic, "Zinc, copper and manganese enrichment in yeast Saccharomyces cerevisiae," Food Technology and Biotechnology, vol. 42, pp. 115-120, 2004.

[50] S. K. Yalcin and Z. Y. Ozbas, "Effects of $\mathrm{pH}$ and temperature on growth and glycerol production kinetics of two indigenous wine strains of Saccharomyces cerevisiae from Turkey," Brazilian Journal of Microbiology, vol. 39, no. 2, pp. 325-332, 2008.

[51] A. A. Eddy and A. D. Rudin, "The structure of the yeast cell wall. I. identification of charged groups at the surface," Proceedings of the Royal Society B: Biological Sciences, vol. 148, no. 932, pp. 419$432,1958$.

[52] M. Malm, "Changes in the electrical charge of yeast cells treated with sodium fluoride," Nature, vol. 157, no. 3996, pp. 731-732, 1946.

[53] H. O. Udeh, T. E. Kgatla, and A. I. O. Jideani, "Effect of mineral ion addition on yeast performance during very high gravity wort fermentation," International Journal of Biological, Biomolecular, Agricultural, Food and Biotechnological Engineering, vol. 8, pp. 1208-1216, 2014.

[54] K. Koyama and M. Seki, "Cultivation of yeast and plant cells entrapped in the low-viscous liquid-core of an alginate membrane capsule prepared using polyethylene glycol," Journal of Bioscience and Bioengineering, vol. 97, no. 2, pp. 111-118, 2004.

[55] H. Y. Wang and D. J. Hettwer, "Cell immobilization in k-carrageenan with tricalcium phosphate," Biotechnology and Bioengineering, vol. 24, no. 8, pp. 1827-1838, 1982.

[56] I. Mariam, K. Manzoor, S. Ali, and I. Ul-Haq, "Enhanced production of ethanol from free and immobilized Saccharomyces cerevisiae under stationary culture," Pakistan Journal of Botany, vol. 41, no. 2, pp. 821-833, 2009. 

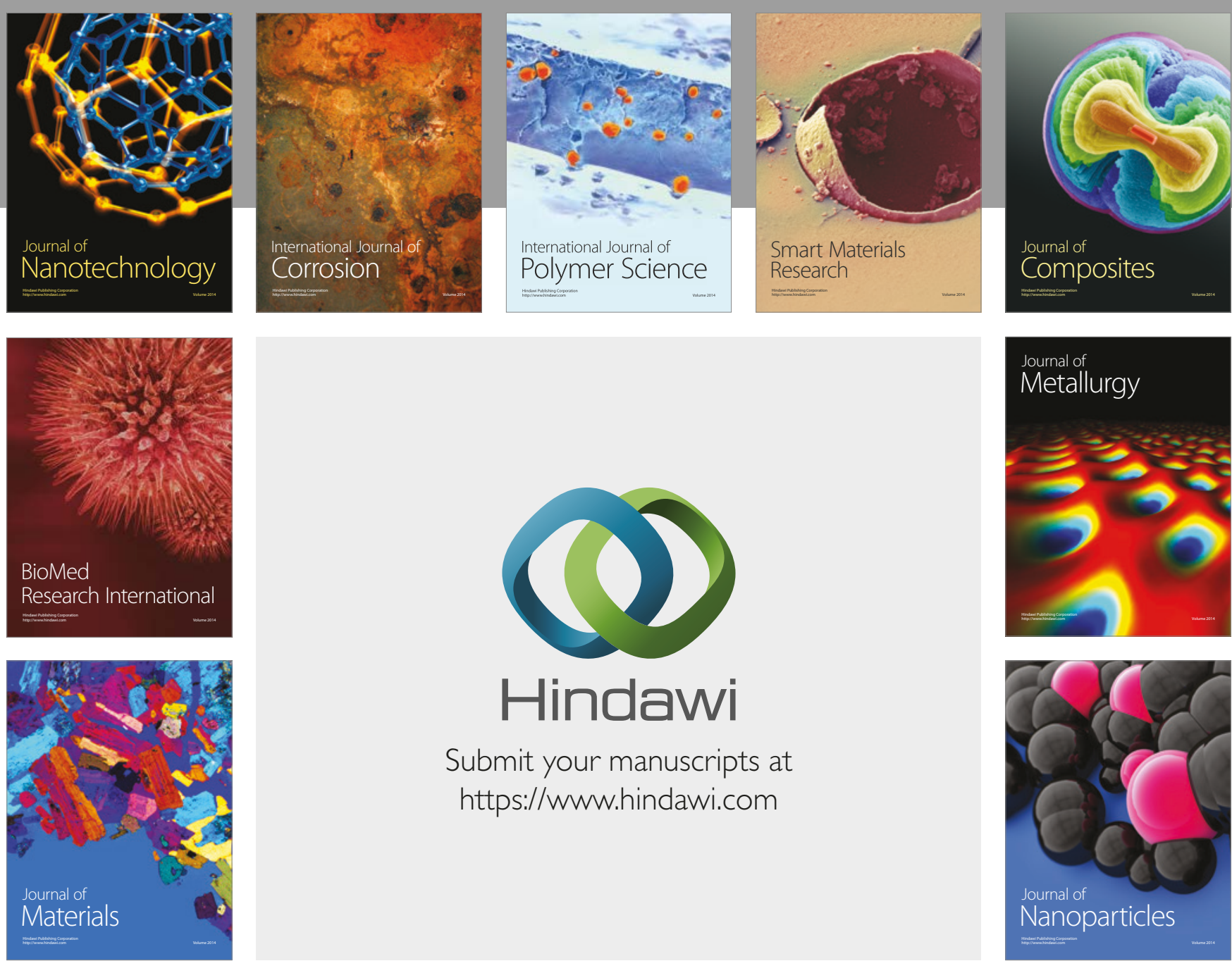

\section{Hindawi}

Submit your manuscripts at

https://www.hindawi.com
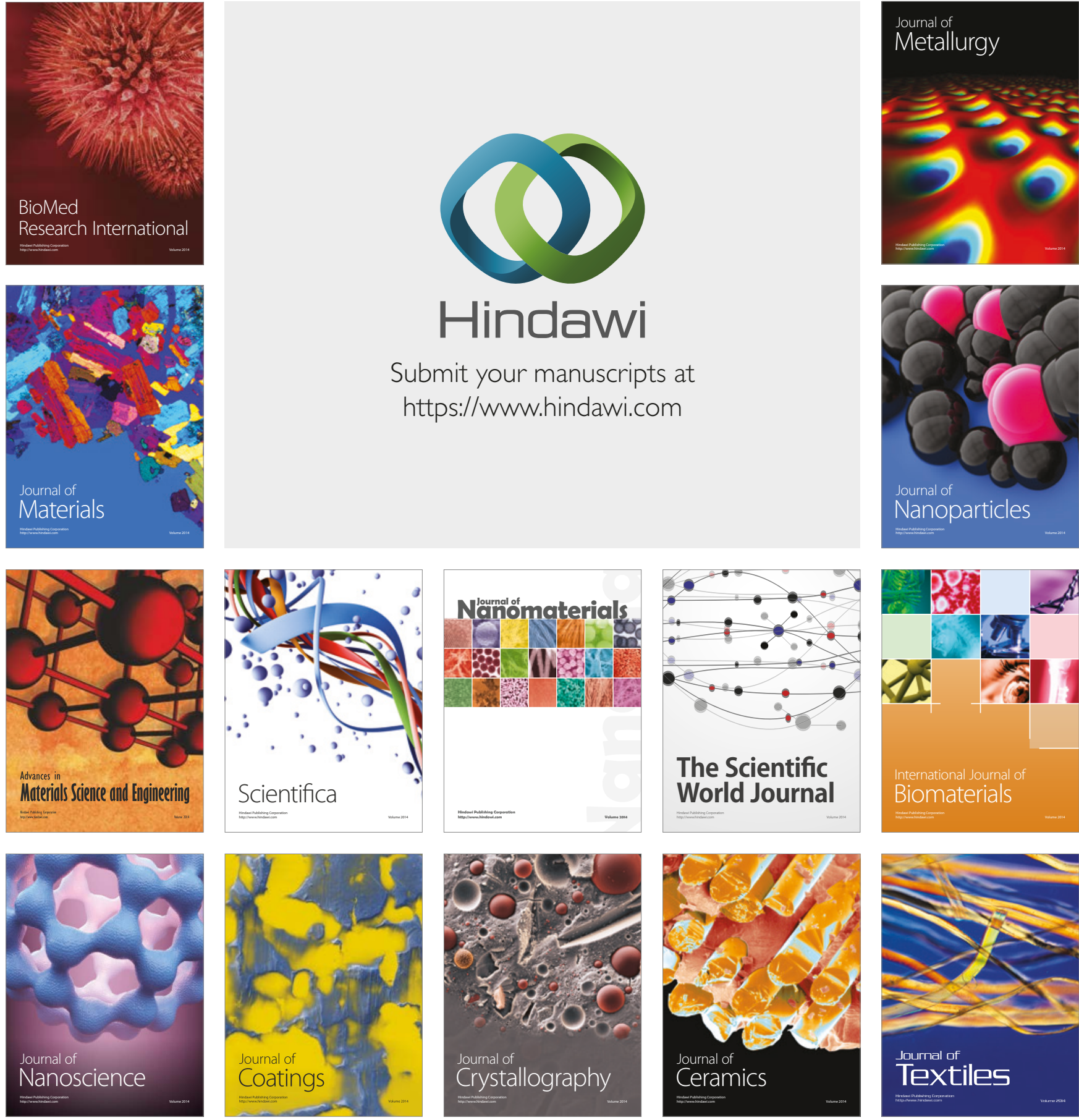

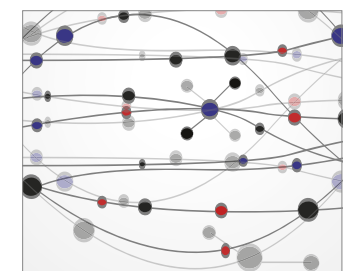

The Scientific World Journal
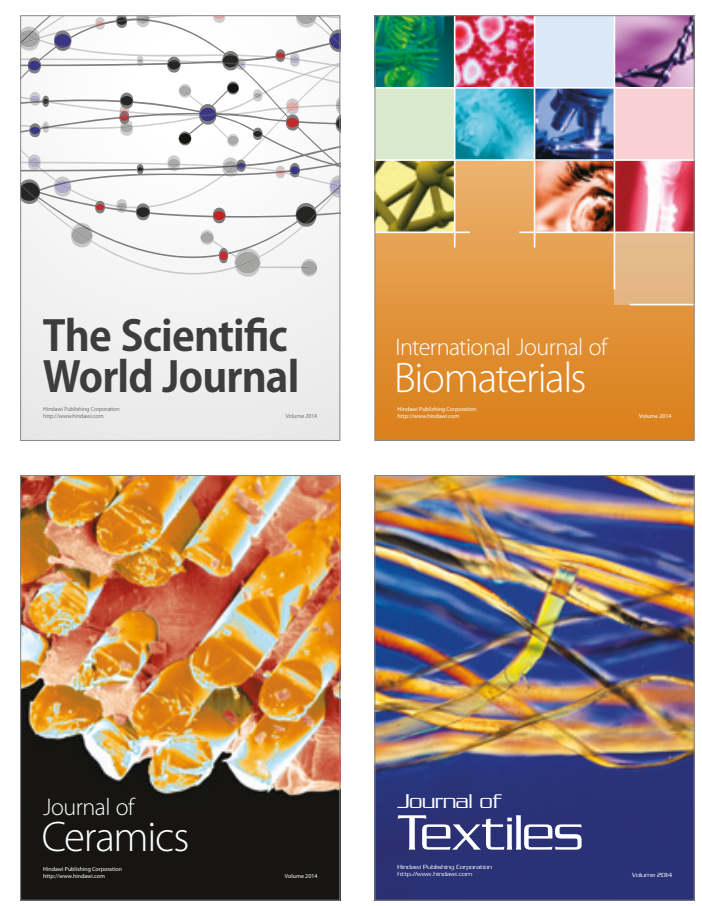